\title{
Fingermark age determinations: legal considerations, review of the literature and practical propositions
}

\author{
Girod A. ${ }^{a}$, Ramotowski R. ${ }^{b}$, Lambrechts S. ${ }^{c}$, Misrielal, P. ${ }^{c}$, Aalders M. ${ }^{c}$, Weyermann C. ${ }^{a}$ \\ ${ }^{a}$ Ecole des Sciences Criminelles, University of Lausanne, Batochime, CH-1015 Lausanne, Switzerland \\ ${ }^{\mathrm{b}}$ United States Secret Service, Forensic Services Division, 950 H Street NW, Washington, DC 20223, USA \\ ${ }^{\mathrm{c}}$ University of Amsterdam, Department of Biomedical Engineering and Physics, Academic Medical Center, \\ Meibergdreef 9, 1105 AZ Amsterdam, The Netherlands
}

\begin{abstract}
:
The question of the age of fingermarks is often raised in investigations and trials when suspects admit that they have left their fingermarks at a crime scene but allege that the contact occurred at a different time than the crime and for legal reasons. In the first part of this review article, examples from American appellate court cases will be used to demonstrate that there is a lack of consensus among American courts regarding the admissibility and weight of testimony from expert witnesses who provide opinions about the age of fingermarks. Of course, these issues are not only encountered in America but have also been reported elsewhere, for example in Europe. The disparity in the way fingermark dating cases were managed in these examples is probably due to the fact that no methodology has been validated and accepted by the forensic science community so far. The second part of this review article summarizes the studies reported on fingermark dating in the literature and highlights the fact that most proposed methodologies still suffer from limitations preventing their use in practice. Nevertheless, several approaches based on the evolution of aging parameters detected in fingermark residue over time appear to show promise for the fingermark dating field. Based on these approaches, the definition of a formal methodological framework for fingermark dating cases is proposed in order to produce relevant temporal information. This framework identifies which type of information could and should be obtained about fingermark aging and what developments are still required to scientifically address dating issues.
\end{abstract}

Keywords: fingerprint age, composition, dating, aging models, absolute age, alternative hypotheses

Corresponding author: aline.girod@unil.ch 


\section{Introduction}

Fingermarks have been used for more than a century for identification purposes during investigations and as evidence in court [1-3]. While the use of such marks for identification generally creates a strong link between a location or object and a person, there are no validated scientific methods for accurately determining the time of contact between the mark and the surface. However, this information is directly linked to the relevance of these marks, (i.e. if they were left during the crime by an implicated person) [4, 5], and thus can be crucial for the resolution of a case. This explains why suspects often raise alternative temporal explanations (legitimate or not) for the presence of their fingermarks at the crime scene.

After a survey of more than two dozen American court cases, it became clear that there was no consensus regarding how these courts admitted testimony related to the age of crime scene fingermarks. In fact, some expert witnesses were allowed to give relatively precise conclusions about the age of fingermarks while others stated that such specific age determinations could not be made (i.e., the age of the marks was indefinite). However, these conclusions raised controversies among the forensic science community because they were rarely based on systematic scientific research or tested comprehensively and validated before their implementation [6-11]. This uncertainty shows that the development and validation of a reliable fingermark dating methodology would be particularly important in forensic science casework.

Therefore, this article aims to address the issues associated with fingermark age testimony in legal proceedings and in the literature, show the limits of current approaches, and assess the potential of new developments in the formation of a framework for fingermark age determinations (sometimes referred to as "fingermark dating"). The first part focuses on court cases highlighting the practical issues; the second part critically reviews dating methods that have been proposed in the literature; and the third part proposes a pragmatic dating framework based on the modelling of aging parameters in order to identify the limits and requirements for the application of such methodologies in practice.

\section{Legal considerations based on previous court cases}

Although the fingermark identification community (e.g., International Association for Identification (IAI), the Scientific Working Group on Friction Ridge Analysis, Study, and Technology (SWGFAST)) as a whole rejects the notion of assigning a specific age to a particular fingermark, there are numerous examples of examiners providing such testimony in court (see Table 1). However, neither the IAI nor SWGFAST has formulated an official policy on this issue. Most of the standard fingermark texts emphatically state that it is essentially impossible to precisely determine the age of latent marks [12]. Champod et al. [13] actually recommend that "... an age estimation should never be based solely on the quality of a developed mark..." and that "...it is generally considered that the determination of the age of a latent finger or palm mark on a particular piece of physical evidence is not possible." A similar statement was made by the UK Home Office in their Manual of Fingerprint Detection Techniques, "It is however impossible to determine reliably the age of a fingerprint by observation of its reaction with a fingerprint detection process." [14]. Nonetheless, there are numerous reported instances of judges allowing or attorneys requesting expert witnesses to provide precise age determinations (with varying levels of success).

A relatively short review of 28 court cases where the age of fingermarks was implicitly or explicitly discussed [15-42] showed that age estimations were never supported by robust 
scientific procedures (even when limited experiments were attempted). They were often generally based solely on the experience of police officers and fingermark experts and were stated in the form of subjective evaluations of the quality and contrast of the developed marks (e.g., cases 9, 11, 15, 17, 23). On several occasions, the experts actually stated that it was impossible to estimate the exact age of fingermarks, but nevertheless provided the court with a personal opinion based on their experience (e.g., cases 10,14, 17, 28). In a significant number of the court cases reported in Table 1, the experts identified the mark(s) as being "fresh" (with estimates ranging from 2 hours up to 1 week). In most of the cases cited in table 1, the appellate court upheld the original ruling (e.g., cases 1, 8, 10, 15, 18, 22, 24, 27, 28), while in other cases the court reversed the original decision (e.g., cases 4, 12, 14), often basing its ruling on the qualifications of the expert witness or lack of a sufficiently specific age estimation for the fingermark(s).

Although Professor Andre Moenssens states emphatically that "It is not possible to determine accurately how long a latent impression will remain on an object or how old an impression is," he also concludes that "At best, print age is the studied opinion of an expert based on the extent of his own experience and investigation." [12]. The central question then appears to be how much weight should be given to such opinions. Judges are often inclined to allow such testimony to be presented the jury. This outcome is due to the role of the trial judge as being a "gatekeeper" concerning the admissibility of evidence. Judges tend to allow such testimony into evidence under the expectation that vigorous cross-examination will properly test the expert witness's opinion. Ultimately, the judge determines the admissibility of the witness's testimony, and the jury decides the proper value or weight to his/her testimony in reaching a verdict.

In some situations it is left up to the defence attorney to prove alternative explanations for the presence of the fingermark(s). On the other hand, in State v. Scott, the court noted that, "The burden is not upon the defendant to explain the presence of his fingerprint but upon the State to prove his guilt." [27]. In State v. Cline, the court quoted United States v. Baller [43] (which debated the admissibility of voice spectrograms), “...it is better to admit relevant scientific evidence in the same manner as other expert testimony and allow its weight to be attacked by cross-examination and refutation." [39] With specific regard to fingermark age testimony, the Cline court stated that "... while the age of a latent print cannot be established with complete accuracy, experienced examiners can proffer an opinion regarding the age of a latent print based on the examiner's experience and investigation." [39] In Ivey v. State, the court emphasized the need to determine that fingermarks "...could have been made only at the time the crime was committed." [44] These cases (as well as those examples highlighted in the next two sections) tend to show a lack of consensus among courts in the United States as well as a pressing need for the forensic research community to provide guidance on assessing the value of temporal evidence.

\subsection{Issues Related to Scientific Testing/Admissibility of Testimony}

Some court rulings as far back as the 1960s began to challenge the notion that expert witnesses could provide accurate testimony as to the age of a deposited fingermark. In Beasley v. State [16], the court ruled:

In order for an expert fingerprint witness to express an opinion as to when finger prints were placed on a given object, a 'control test' must first be conducted. In a 'control test' a series of latent finger prints are placed on a surface and controls are placed on all governing factors such as air, 
humidity, dust, and heat in order to determine how long the prints would remain on a given surface and could be dusted out [visualized with powder].

The Beasley court also noted that "The witness admitted on voir dire examination he had not conducted a control test..." and that "He [the expert] should not, however, have been allowed to express his opinion as to the time they [the prints] were placed there [on the automobile]." Ultimately the Beasley court concluded that "To allow him [the expert] to so testify was prejudicial error." Ultimately, the judgment was reversed and a new trial was ordered. In defending its ruling, the Beasley court stated, "...the facts on which an expert opinion is based must permit of reasonably certain deductions as distinguished from mere conjectures." Furthermore the court noted that "...it is essential that the principle or discovery from which a deduction is to be made shall have been sufficiently established to have gained general acceptance in its particular field of science." Similarly, in Levine v. Remolif, the court ruled that an expert witness may not give an opinion if "...his conclusions to a substantial degree were the result of guesswork." [45]. In this case, the lower court had ruled to strike the testimony of one of the expert witnesses because he "...had no definite criteria upon which he could base a scientific conclusion... and his testimony, for that reason, is nothing more than a guess and is incompetent." The Nevada Supreme Court affirmed the lower court's ruling and its decision to strike the testimony of the expert witness from the record, noting that determining the competency of an expert witness is largely within the discretion of the trial judge.

In State v. Granberry [24], the appellant cited the Beasley v. State decision, noting the need for conducting controlled testing prior to being able to make a determination of the age of the fingermark. In this case, the fingerprint expert testified that "I cannot give a scientific time element, like minutes or seconds, something of that nature. I can give you a scientific opinion whether the print was fresh or old, based on the prints I have seen in the past of similar developments." The appellant challenged that no scientific testing had been done and that the expert had given an "educated guess" as to the age range of the fingermarks. The Granberry court disagreed, noting that the ruling in Beasley did not apply since the expert "...made no attempt to give such a definitive answer, but rather gave a broader period of time in which the prints were most likely made." Interestingly, the fingerprint expert in the Granberry case testified that the fingermarks were fresh and between 2-24 hours old.

In Hearn v. State [22], testimony from the fingerprint expert, Lt. Roger Meurer, indicated that the age of the fingermark developed on the burgled safe was between 10-24 hours. This relatively narrow range for the age of the fingermark was based on some experiments that he had conducted. The appellant asserted that the original court erred in failing to exclude the fingermark age related testimony. The appeals court overruled the appellant's challenge stating "We have examined the testimony of Lt. Meurer and the experience upon which he predicated his opinion and have concluded that he was competent to express the opinion which he gave." The court went on to note that the expert "...testified fully concerning the experiments and was thoroughly cross-examined about them." Ultimately, the Hearn court found the appellant's argument unpersuasive and the original judgment was affirmed.

In Edwards v. State [32], the appellant challenged the testimony of the State's expert as to the age of fingermarks left at the scene of the crime. Citing Hearn v. State, the appellant argued that the proper predicate was not laid for testifying about the age of the marks because there was no evidence that certain experiments conducted by the expert witness were performed under "certain conditions." It was implied that such testing would require controlled testing 
that duplicated the conditions at the scene of crime where the fingermark was originally recovered. The Texas Court of Appeals disagreed, noting that “...the prosecutor's stated purpose was to head off anticipated testimony of appellant to the effect that he had been in the house of the victim some six months prior to the murder and could have made the prints on that occasion." Furthermore, the Edwards court noted that "All the prosecutor was attempting to elicit from the expert, and in fact all that he did elicit, was the prints were fresh or recent as opposed to being six months old." The Edwards court found no error in admitting this testimony and ultimately affirmed the original judgment.

In Commonwealth v. Crawford [26], the police laboratory personnel had performed some experiments to determine the age of the fingermarks, but were unsuccessful. Although the fingermark expert originally noted that there was no scientific way to "date" marks, he did go on to say (over vigorous attempts by the defence to prevent him from doing so) "...the foreign matter [blood on top of the three partial palm marks] that was found and finally analysed had to be placed there during or about the time of the commission of the crime." Upon cross examination, the expert witness admitted that that the Bureau of Alcohol, Tobacco, and Firearms, in Washington, D.C., had told him that there was no way in which the fingermarks could be dated. The Crawford court determined that the fingermark age testimony was "...beyond the range of training, knowledge, intelligence, and experience of the prosecution's expert witness." The court ruled that this testimony should not have been admitted into evidence and reversed the original judgment and ordered a new trial. ${ }^{1}$

Finally, in People v. Jiminez [36], extensive experiments were performed by the expert to determine the age of fingermarks left on beer bottles at a crime scene. A detailed description of the experiments performed by the expert was published in the Journal of Forensic Identification [46]. The expert witness ultimately testified that based on the experiments, the fingermarks were not more than 24 hours old. Interestingly, in this particular case, the defence did not choose to challenge the fingermark age testimony during the original trial and thus it was not an issue considered by the appellate court. However, a review of the experimental design used and conclusions drawn from these experiments was published in the following issue of the same journal [7]. Regarding the fingermark aging studies performed, the authors concluded that "Mr. Schwabenland's opinion that 'all relevant factors were known and every effort was made to ensure complete accuracy' is faulty." The authors noted that critical factors like residue composition, viscosity, and quantity would be essential in determining the evaporation rate and thus the age of the fingermark. Finally, they concluded that "lacking these [environmental] variables, no testing or experiment can be considered as complete or accurate."

While there is no litmus test specifically required by American courts to permit the admission of testimony related to the age of a developed fingermark, it is clear that the aforementioned cases demonstrate that judges can require expert witnesses to produce a scientific foundation for their fingermark age related testimony. However, even when such studies are performed, there is no guarantee that the experiments were performed properly. The current lack of any validated method for determining the age of a fingermark is reflective of the inherent difficultly in controlling all of the variables associated with the aging process.

\subsection{Issues Related to Accessibility of Evidence}

\footnotetext{
${ }^{1}$ It should be noted that there has been significant controversy surrounding this case. As part of a subsequent appeal, there were questions about whether the expert's reports and testimony had been altered to support the prosecution's theory of the case. The defendant was ultimately released.
} 
In a number of cases (e.g., cases 3, 4, 6, 7, 13, 21), the fact that the fingermark was on an item that was publically accessible made a significant difference in these courts' decision to reverse the original judgment. In Townsley v. United States [18], the court reversed the original decision stating that "Appellant's fingerprints were found in a place always accessible to the public and could have been impressed at any time." The Townsley court also noted that "It is possible that appellant touched the glass in an incident so trivial that he simply did not remember it when he was arrested, three months later." Similarly, in United States v. Garside [20], the fingermark expert noted that the defendant's marks could have been on the evidence (a local map) for an indefinite period of time. The court noted that "the map could have been innocently handled by him months before the robbery and found its way into the car in any number of ways without his participation or knowledge." Because the map was accessible to the public in a store, the court reversed the original judgment against the defendant Garside. In its ruling in the Matter of J.C.M., Jr. [35], the court noted that the failure to establish an accurate deposition age (or age range) for the fingermark could ultimately "...jeopardize the liberty of every person who ever touched anything later found at the scene of a crime."

In other cases (e.g., cases 5, 25, 29, 30, 31, 33) the fact that the fingermark was found on an item that was not accessible to the defendant resulted in the courts affirming the original judgments. In Patten v. United States [19], the presence of fingermarks on a paper bag containing burglary tools and found on a roof of a burgled building were at issue. The court noted that the appellant had stressed that "...the mobile character of the paper bag, coupled with the common availability of such bags and the fact that the fingerprints could have been on it for as long as six months..." offered a plausible explanation for how his marks ended up on the bag. However, the court, in affirming the original judgment, ruled that "...the object upon which the prints were found was discovered in an area generally inaccessible to appellant or any member of the public." In State v. Nash [30], a fingermark described as "...dark and clear and fresh" was found on the inside portion of a sliding glass door. Since the owner testified that the defendant had never been in her apartment for any reason, the court concluded that the "...jury could reasonably infer that Nash's fingerprints could not have gotten on the sliding door without the intervention of criminally culpable conduct on his part" and affirmed the original judgment. In State v. Phillips [31], the appellant claimed that his marks were on the stolen television because he had lived with the burglary victim in the past. The victim claimed that he had purchased the television set after the appellant moved out of his apartment. In affirming the original judgment, the court stated that the “...appellant's contention that he placed his fingerprints on the television set either while residing at the apartment or while visiting becomes unreasonable." In State v. Wynn [34], the appellant claimed that his fingermarks were on the glass beer mug (that contained in excess of $\$ 150.00$ in change) because he had previously attended a party at the victim's apartment. He testified that people were in and out of the apartment all day during the party. However, the court (in affirming the original judgment) stated,

Evidence that defendant's fresh fingerprints were found at the scene of the crime at a place not generally accessible to defendant under circumstances of this case, was sufficient to make a submissible case from which the jury could infer that defendant was guilty of the crimes charged against him, and sufficient to exclude any hypothesis of his innocence. 
It is clear that the age of developed fingermarks plays a critical role in determining whether or not a defendant/appellant had legal access to the evidence. As can be seen in the cases listed in table 1, expert witnesses often take a holistic approach when proffering an opinion on the age of fingermark. When based on experience rather than sound scientific data and studies, such opinions can lead to erroneous conclusions.

\section{$<<$ INSERT TABLE 1 NEAR HERE $>$}

\subsection{Fingermarks Developed in Unusual Circumstances}

Although detailed written reports and comprehensive court case reviews are difficult to find in Europe, the same lack of consensus and misconception concerning fingermark dating cases can be identified from the forensic literature, as well as in Israel and New Zealand [13]. In fact, among practitioners, the belief that easily enhanced/good quality fingermarks are fresh is still broadly accepted and some courts are willing to admit such expert opinions. This belief persists even if its origin is very old, as illustrated by Robert Heindl, pioneer of dactyloscopy in Germany, who wrote in 1927 that "... older fingermarks were harder to enhance..." [47]. While Heindl's observation may be true, this cannot be generalised or misinterpreted to mean that fingermarks that are difficult to enhance are always old or that (even worse) fingermarks that are easily enhanced are always fresh. While most reported age estimation testimonies lead to convictions of the accused (sometimes based on no other contextual elements than the age of fingermarks), several court cases have resulted in acquittal based on the fact that fingermarks could persist for a long time (i.e., an alternative and legitimate explanation for the presence of the fingermarks on the object or at the crime scene was accepted). The majority of cases where fingermark age testimony resulted in a conviction tended to be based on fingermark appearance (i.e., "quality" or "contrast") (e.g., cases 16, 17, 28), while some relied on the fact that no other marks were found to overlap those of the accused (e.g., cases 20 and 28 in Table 1).

The complex interactions between fingermark, substrate, and environment can combine to preserve or greatly diminish the ability to recover it. A comprehensive review of the factors that can affect the condition and composition of fingermark was previously reported [48]. Many publications have mentioned the development of fingermarks in unusual circumstances. Some examples include: 110-day-old fingermarks developed with iodine [49], good quality 2year-old fingermarks on external windows using powder [50], a 35-year-old fingermark developed with ninhydrin [51], a 15-year-old fingermark developed with physical developer (PD) [52], 55-year-old fingermarks developed with PD on an electrics bill [53] and a fingermark developed with aluminium powder on a bottle after it had been washed with soap and water [54]. Illsley [55] reported a study involving fingermarks developed with cyanoacrylate fuming and black powder on a knife blade. The marks were then lifted with transparent lifting tape and transferred to an index card. Illsley was able to repeat this procedure 559 times before the lifts were no longer of identification value. Such experimental results were also observed in another unusual case [56]. In August 1983, a suspect was arrested, prosecuted, and convicted of burglarizing a church. A Los Angeles Police Department (LAPD) fingermark examiner had developed two fingermarks (left middle and ring fingers) from the point of entry using powder. Approximately one year later, the LAPD responded to another burglary of the same church. A different fingermark examiner was able to enhance a left middle and ring finger impression of a suspect at the point of entry. The suspect was eventually identified as being the same individual who had committed the first crime. Since this person was still serving time in prison for the previous conviction, it was determined that the second examiner had powdered and lifted one-year-old fingermarks 
from the previous crime. However, it is clear that allowing fingermark age testimony based solely on an expert's experience can lead to erroneous conclusions.

Moreover, some experiments have shown how difficult it is to draw conclusions based only on the visual observation of the quality of natural or enhanced fingermarks (Figures 1 and 2). In fact, natural fingermarks on glass slides showed no significant difference after 5 weeks, as the ridge detail remained of comparably very good quality (Figure 1). For enhanced fingermarks, while the contrast between the marks and background decreased very quickly, the number of minutiae remained consistent over time when the mark remained undisturbed, and no large differences could be observed between 1-hour and 6-week-old fingermarks (Figure 2). Thus, the initial state of the transferred fingermark may to some extent have more influence on the quality than the passage of time [48].

\section{<<INSERT FIGURE 1 NEAR HERE〉>}

\section{<<INSERT FIGURE 2 NEAR HERE $>$}

Indeed, several published studies have investigated how fingermarks age based on powdering experimentations. Barnett and Berger examined the effects of temperature and humidity on fingermarks [57]. They found some rather surprising results, including that marks stored at high relative humidity were of poorer quality than those stored at a lower relative humidity. Similar results were reported by Bluhm and Lougheed [58]. Barnett and Berger found that it was not possible to determine whether a fingermark was fresh or several weeks old by examining the quality of the mark lift or observing how the fingermark develops when powder is applied. They concluded, "The identification technician who examines latent fingerprints in the laboratory is not in a position to make any statement concerning the age of the print." Balloch examined the ability to powder fingermarks subjected to a normal office environment on a glass surface over time [59]. In some instances, fingermarks dusted after a few months appeared as sharp and clear as those developed after a few days. Belcher reported similar results [6]. Factors influencing the quality of fingermark enhancement (in particular, fingermark powders) were rarely mentioned and never comprehensively debated. While environmental conditions (e.g., see cases 7, 11, 16 and 26 in Table 1) and enhancement methods (e.g., see cases 9, 11, 15, 23, 25, and 27 in Table 1) were discussed on several occasions, donor characteristics, substrate influence and deposition conditions were rarely addressed. Fingermark aging is a complex process and the reliability of each potential dating technique has to be comprehensively and thoroughly tested before considering any implementation in practice. The unscientific approach used by experts in some of the above mentioned court cases could ultimately lead to erroneous conclusions.

Finally, it is interesting to note that among the 28 court cases mentioned in Table 1, most of the testimonies appeared before DNA analysis had reached maturity in the late 1990s. Fingermarks were generally the only forensic evidence mentioned. Today, such dating questions are commonly asked related to other types of evidence, such as blood or DNA [60, 61], and temporal questions have indeed been recognised as essential, but complex, issues for forensic science $[4,5]$. Weyermann and Ribaux noted that "Estimating the age of a trace is a rather difficult challenge in most cases, because ageing processes are influenced by many factors apart from time, some of them considerably accelerating or inhibiting the ageing" [4]. Thus, it is generally recognized that more research is needed in order to be able to scientifically address fingermark dating questions in practice. In addition, most of these cases predate the 1993 Daubert [62] ruling on the criteria for admissibility of evidence. These criteria (whether the theory or technique is falsifiable; whether it has been subjected to peer 
review; the known or potential error rate; existence and maintenance of standards; general acceptance of theory or technique by a relevant scientific community) would have made introducing controversial testimony (e.g., age determination) more difficult. The release of the National Research Council's report Strengthening Forensic Science in the United States: A Path Forward [63], which criticized most non-DNA forensic disciplines as not sufficiently scientifically based, also could lead to more admissibility challenges.

\section{Critical literature review of fingermark dating methods}

It is possible to separate the research concerning fingermark dating in three different categories based on:

(1) Investigative information,

(2) Visual changes in fingermark physical characteristics (e.g., minutia and pores),

(3) The aging of fingermark chemical characteristics (i.e., fingermark composition).

\subsection{Investigative information}

The first category concerns the use of investigative information in order to estimate the maximum age of a fingermark [9, 13, 64]. For example, if a surface on which a relevant fingermark was found is usually cleaned every week, it is possible to infer that the maximum age of this fingermark is one week. This type of dating gives indirect contextual information and as such, corresponds to what was previously defined as contextual time tags [4].

Real cases recently summarized by Bunter [65] also highlighted that a holistic approach to the examination of the evidence and surrounding environment should be used in order to avoid making incorrect conclusions based solely on the quality of fingermarks or considering that weather conditions always have damaging effects. For example, in one case, CSI officers found a hand mark on a surface that had been cleaned down several times and even painted over recently. Thus, they considered that this mark was fresh. However, a careful observation of the surrounding environment of this mark revealed that it had been left in an old layer of paint and had been pressed into the surface, thus being rather old and not fresh [66]. Another case from Australia described a fingermark that had survived two years on an external window but that it exhibited really good ridge quality. Experienced fingermark officers considered this fingermark as fresh, even if the identified person, another police officer, said he had been there with a colleague two years ago but not recently. Further investigations showed that other very good quality fingermarks on the window belonged to this police officer's colleague. The police officer and his colleague had not worked together since they visited the premises for another case two years ago. It was this information that allowed investigators to draw the conclusion that the police officer was telling the truth and that the questioned fingermark was not recent [50]. Davidson reported a similar case, where a fingermark survived more than nine years on the external surface of a door exposed to Western Australian weather but showed very good ridge details when developed with magnetic powder. Only contextual and investigative information were able to prove that this fingermark was not fresh [67].

Cohen also reported cases where fingermarks of really good quality appeared and were thus considered as fresh, until other investigative information allowed identifying particular conditions leading to the conservation of the mark [68, 69]. For example, a fingermark was recovered more than two years after deposition and could be used for identification purposes because of its fixation onto a metal window frame [69]. This author also noticed that fingermarks could resist cleaning products and that careful consideration of other investigative factors should be made in order to not wrongly consider a fingermark as fresh 
[68].

All of these cases showed that investigative information could be of great help for the resolution of cases. Therefore, this kind of information should be collected whenever possible. However, it should also be noted that this information could be wrong or imprecise and lead to biased inferences. Thus, it is important to use this kind of information while keeping in mind that the fingermark is labile in nature and that it must be taken in context with other sources of information.

\subsection{Visual changes of physical characteristics}

A second category makes use of the visual changes of physical characteristics to estimate the age of fingermarks. One study proposed the use of the general appearance of fingermarks, before or after enhancement, as an aging parameter [64]. In fact, this proposition corresponds to what was often mentioned in the court cases summarised above (see Table 1). In this approach, the quality of a mark and the ease of its enhancement are considered as reliable aging parameters. However, this kind of dating was often criticised because the changes observed are not only due to age but also due to other influence factors [8, 10, 49, 70, 71]. Attempts were made to take some of these influence factors into account, as for example in a case reported by Schwabenland [46] (see case 23 in Table 1). The fingermark expert testified about the age of fingermarks based on experiments conducted to recreate the conditions under which the mark and substrate were subjected. However, all the relevant factors were not properly addressed [7]. In fact, the unique chemical composition of the deposit itself was not adequately considered, as Schwabenland's fingermarks were used for the experiments and not those of the suspect. Furthermore, his evaluation was based solely on the comparison of the enhancement quality of the test marks with the question marks, without clearly specifying which criteria were observed. His evaluation was thus rather subjective and no blind testing was reported. Finally, adequate photographic documentation was not available to allow independent verification of results [7]. Recently, two other articles mentioned similar experiments using enhancement powder, one in a practical context [72] and the other in laboratory conditions [73]. While the first article considered influence factors but not the initial composition, the second one investigated differences due to initial composition (as many donors were used) but not to influence factors. Despite the drawbacks of these studies, they both revealed that aging patterns could be observed (e.g., reduction in the width of ridges and on the percentage of visible ridges). However, further studies are still necessary in order to precisely evaluate the potential of this approach.

Another age determination approach, based on physical characteristics but that also takes into consideration the initial fingermark composition, has been reported to be in routine use since 1970 by the Dactyloscopy Department of the Main Police in Warsaw, Poland, for assessing the age of fingermarks left on smooth, non-porous surfaces $[74,75]$. The changes occurring in the morphology of the ridges (e.g. width, thickness) over time were precisely studied, testing different influence factors (deposition and environmental conditions) and using numerous fingermarks from different donors. The evaluation and photography of approximately 20,000 fingermarks subjected to various aging conditions lead to the creation of an image database used by fingermark experts to gain experience on the appearance of different degraded fingermarks. When a questioned fingermark has to be dated, images are taken in controlled conditions (e.g. same illumination, same angle). Then, comparison fingermarks from the suspect are collected on substrates matching the one on which the question mark was found. These comparison marks are then aged in conditions similar to the ones under which the questioned mark was subjected, based on information provided in reports made at the crime 
scene (e.g., temperature, humidity, pollution, rainfall). Images of these comparison marks are then taken and compared with the questioned marks. Finally, a probabilistic estimation of the age is given based on expertise, knowledge of fingermark degradation and statistics from the database. This approach was criticised principally because of its probabilistic component [76], but this criticism does not seem well-founded as the probabilistic approach has been considered by many other authors as relevant to forensic issues [13, 77, 78]. However, this approach might raise other concerns because the estimation is principally based on the fingermark examiner's expertise and it was highlighted that such expertise can be biased and lead to subjective inferences $[8,79,80]$. Furthermore, as this approach is only compatible with smooth, non-porous substrates and that it is actually used only in Poland, it is still far away from a generally accepted and applicable fingermark dating methodology. A similar approach was reported in a more recent paper [81]. The number of minutiae, thickness of valleys and ridges, presence of pores, and the quantity of DNA were considered in this study as reliable aging parameters, as they showed reproducible modifications over time. It was thus proposed to compare these parameters between the questioned mark and known aged marks. However, few details were given about the practical application of this approach - especially how the comparisons were really conducted and under what conditions the aging processes were actually reproducible.

Another dating approach used a chromatic white-light (CWL) contactless sensor to study fingermark physical characteristics over time [82]. The CWL sensor generates a topographic image of different types of samples using the chromatic aberration of light in the focusing lens to obtain depth information. Numerous experiments were conducted using this sensor and measuring the contrast differences occurring between the fingermark and substrate over time. It was observed that contrast diminished when the age increased (following a logarithmic law). The fingermarks used for the first experiments originated from one single donor and were aged between 0 and 24 hours in laboratory conditions on smooth surfaces. A longer aging period using different donors highlighted reproducibility difficulties due to the inter-variability (variability between different donors) and intra-variability (variability among fingermarks of same donor) of the fingermark's appearance. Furthermore, different influence factors potentially affecting the contrast were tested and sweat composition, temperature, humidity, wind, UV radiation, surface type, contaminations, scan resolution, and measured area size were determined to have a major impact. Contact time, contact pressure, and smearing of the mark were determined to be of minor importance. Thus, this approach may have some potential, but influence factors are important issues that have not been resolved to date. A further practical limiting factor lies in the fact that CWL sensors can only be used on smooth, clean surfaces.

Finally, another approach used an electric field microscopy system to study changes in the electrical charge of fingermark residue after deposition [83]. Two main observations were made in this study. First, the spatial resolution of the resulting images was found sufficient for identification purposes. Second, the quantification of the decay of the surface charge, being well defined and regular, might be considered as a candidate aging parameter for fingermark dating. However, this decay is largely material dependent and further studies should be conducted in order to evaluate the effect of influence factors on this potential parameter.

\subsection{Aging of fingermark chemical characteristics}

The third category of fingermark dating techniques is based on the aging and changes of fingermark chemical characteristics (i.e., fingermark composition) over time. Forensic practitioners have noticed that time affects fingermark composition, principally because of 
differences in enhancement quality, as for example with physical developer, which allows for obtaining better results when applied on older fingermarks than with newer ones [84-86]. Numerous compounds have been found in fingermark residue and are mentioned in different reviews on the subject [48, 87], but only the compounds studied for dating purposes will be addressed here. In general, these research efforts focused on at least one target compound and studied its aging to find reproducible patterns. Angst [88] proposed the use of the migration of chloride ions in paper as an aging parameter. This migration was supposed to be proportional to time and was made visible using silver nitrate enhancement. The diffusion pattern on both sides of the paper was studied. Based on experience and taking into account the humidity level that could influence chloride ion migration, fingermark age estimations were reported. However, this approach was not studied further because it suffered from several major drawbacks. First, the observation of the diffusion pattern and the age estimation was apparently based mainly on subjective observations and no details were given about the evaluation criteria. In addition, the influence of the storage conditions on the chloride ion migration was not precisely known. Finally, this methodology was applicable on paper only.

Other authors proposed the use of thin layer chromatography (TLC) and high performance liquid chromatography (HPLC) to study the behaviour of lipids over time [89, 90], but the results were not conclusive, mainly due to technical limitations. TLC was also used in combination with spectroscopic detection in order to study the varying fluorescence of the separate compounds over time [91, 92]. It was observed that the fluorescence of fresh fingermarks was greenish-yellow, while older fingermarks' fluorescence was orange. Thus, it was hypothesised that this change was due to the presence of riboflavin, the B2 vitamin. However, the final outcomes of these studies were negative as the intra- and inter-variability was far too large [93]. A new study on the autofluorescence of fingermarks was recently carried out in order to identify the compounds responsible for the phenomenon [94, 95]. Protein bound tryptophan (an amino acid) was inferred to be the main source of fluorescence in fresh fingermarks. Furthermore, based on a ratio between the fluorescence of tryptophancontaining proteins and the fluorescence of other oxidation products that are still not known, fingermark aging could be followed in a reproducible way. An age estimation method was proposed that relied both on the oxidation state and the aging rate of a fingermark. By including the rate at which a fingermark ages, the problem of inter-person variability was partially solved. Under controlled laboratory conditions it was possible to estimate the age of $55 \%$ of the fingermarks from male donors, up to three weeks old, with an average uncertainty of 1.9 days [96]. Amino acids were also analysed using liquid chromatography in order to study their stability to light and temperature. It was observed that amino acids are very stable since they do not exhibit any photo-degradation. However, thermo-degradation was observed, but only at high temperatures $\left(100^{\circ} \mathrm{C}\right)$ [97].

Since 1990, important developments have occurred concerning the sensitivity and reliability of analytical techniques, in particular gas chromatography coupled with mass spectrometry (GC/MS), as already foreseen by Olsen [90]. This has led to numerous research efforts about fingermark composition using GC/MS. While the technique is destructive for the marks, it allows for the analysis of many compounds from different substrates. The main aim of these research efforts was the improvement of enhancement techniques through a better knowledge of possible target compounds. Furthermore, the development of fingermark dating methodologies based on chemical modifications was also considered. Results highlighted composition differences between children and adults [98], but not between genders [99]. The inter-variability and intra-variability of the initial fingermark composition and aging was also demonstrated [71, 100-104], as well as the variability of fatty acids over time in comparison 
with the stability of amino acids [105, 106]. Archer et al. [100] showed the reproducibility of fatty acids and squalene aging in fingermarks under controlled conditions, but highlighted the variability occurring with changing environmental conditions (e.g. storage in the light versus in the dark). Other studies based on GC/MS analysis showed the possibility of creating reproducible aging models using lipid degradation and calculating ratios between lipids [71, 107]. However, these studies also noted that influence factors (e.g., donor characteristics, substrate nature, deposition and storage conditions, enhancement techniques) affected the reproducibility of fingermark composition. While the use of ratios of endogenous compounds and the production of different models could reduce part of this variability, further studies are still needed. The variability of fingermark composition has to be taken into account to develop a reliable fingermark dating technique and studies conducted on real fingermarks should be encouraged in order to simulate conditions closer to forensic casework.

Fourier transform infrared spectroscopy (FTIR) was used in 1985 by Humecki on ink traces and he observed changes in the hydroxyl $(\mathrm{OH})$ and carbonyl $(\mathrm{CO})$ infrared absorption band as a function of age [108]. This pioneering research inspired other scientists in different areas of forensic science and FTIR was also used to study the aging of lipid compounds in fingermarks. Antoine et al. [109] observed that fingermark composition changed differently over time in fingermarks of children versus adults, due to differences in the lipid composition. In fact, children's fingermarks showed higher cholesterol and cholesteryl esters amounts, while adults' fingermarks contained large amounts of wax esters and triglycerides. The fingermark composition could thus be a sensitive metric to estimate the age of an individual, as already proposed by Hemmila et al. [110]. Concerning the aging of adult fingermarks only, Fritz et al. [111] did not find any pattern over one month, while another study was able to separate fingermarks into age groups ranging from 0 to 34 days using chemometric tools and observed differences when fingermarks were stored in the light and in the dark [112]. Differences in instrumental parameters and sampling can explain the contrary results obtained in these two studies. This observation again shows that more research should be carried out to better understand influence factors and evaluate the actual potential for fingermark age determination. Furthermore, ATR-FTIR analyses also highlighted that exposure to vacuum conditions $\left(2 \times 10^{-5}\right.$ Torr for $\left.1 \mathrm{~h}\right)$ changed the fingermark composition, as the marks lost $26 \%$ of their mass, which is equivalent to around 5 weeks of ageing under ambient conditions. A significant reduction in the lipid composition of fingermarks was also noted, particularly the loss of tetradecanoic and pentadecanoic acid [113]. It is also interesting to note that hyperspectral imaging could also be used as a tool to investigate fingermark aging [114]. This technology combines the use of spectral information with spatial data and can give interesting results when used for blood dating purposes $[115,116]$.

Recently, advanced techniques in mass spectrometry (MS) linked with different ionisation processes have been developed and offer new capabilities for analysing fingermark residue. For example, matrix assisted laser desorption ionisation (MALDI)-MS was used to study the aging of oleic acid in fingermarks over seven days, highlighting the possibility of creating aging curves [117]. Secondary ion mass spectrometry (SIMS) was also proposed to analyse fingermark composition [118] as well as to determine if a fingermark was left before or after an ink trace (relative dating) [119]. However, these techniques are still under development and have not been validated for use in forensic laboratories.

\section{Propositions for the development of a fingermark dating framework}


Based on the previous sections, it is clear that no method for determining the age of fingermarks has been found reliable enough to be applied to actual casework. Unless corroborative evidence exists to assist the assignment of age to a questioned mark, any opinion provided would be speculative at best. In the near future, one would expect to see such testimony significantly hampered by precise guidelines, as established by the U.S. Supreme Court in its landmark decision (e.g., Daubert v. Merrill Dow Pharmaceuticals [62]). However, this should not preclude researchers from attempting fingermark dating research. Indeed, if enough research is devoted to this subject in the future, it may be possible to propose reliable protocols. Thus, this section aims at describing a possible approach to guide future fingermark dating research, based on recent discussions on the subject [120]. A choice was made to concentrate this approach on the aging of chemical characteristics because this seems to be the most objective, as predicted by Wertheim [10] more than 10 years ago. The key parameters on which this research effort will focus will be described in the first section, while practical considerations concerning the implementation of a dating technique will be made in the second section, highlighting the possibilities as well as the limitations of such an approach.

\subsection{Research on key parameters}

In order to use chemical characteristics to evaluate a fingermark's age, it is necessary that the research focuses on the following key parameters in an iterative process (Figure 3).

\section{$<<$ INSERT FIGURE 3 NEAR HERE $>$}

\section{$\underline{4.1 .1 . ~ T a r g e t ~ c o m p o u n d s ~}$}

A fingermark contains numerous compounds, mainly eccrine and sebaceous in nature [48, 87]. However, in order for these compounds to be relevant target compounds, they should (ideally) fulfil the following criteria:

- The compounds should be detectable in all donors' fingermarks,

- They should be endogenous compounds, which means differentiable from contaminants often found on fingertips (e.g., cosmetics),

- The compounds should be detectable and measurable with analytical techniques easily available in operational forensic laboratories,

- The compounds should show a variability as low as possible when exposed to influence factors that can affect fingermark composition over time,

- The compounds should show reproducible and measurable modifications over time; for example, a decrease or increase of their initial quantity (absolute or relative).

Based on the previous literature review, the lipids available in fingermark residue could be targeted. In fact, they are present in every person's fingermarks, can be analysed with routinely-used analytical techniques (e.g., GC/MS or FTIR), and show reproducible changes over time under controlled conditions. However, some lipids are also often found in cosmetics. Thus, research should focus on identifying the lipids that are specific to fingermark residue. Furthermore, the stability of lipids under different influence factors has not yet been fully studied and future research efforts should focus on studying the impact of these factors. Other potential aging parameters could also be considered; for example, the changes in amino acid fluorescence over time. Unfortunately, their variability when exposed to different influence factors has not been well documented either. Thus, influence factors will always have a crucial impact on fingermark target compounds and as such, on the development of the 
entire fingermark dating process. These factors were recently classified into five categories [48]:

(1) Donor characteristics (e.g., age, diet, and habits),

(2) Substrate nature,

(3) Deposition conditions (e.g., contact pressure or time),

(4) Environmental conditions (e.g. temperature or humidity),

(5) Enhancement techniques (when fingermarks are latent).

Research efforts should focus on the effects of these factors on fingermark composition, most of which are rarely known with any level of confidence in real case scenarios. In fact, when the nature of a factor is known, it can be integrated in aging and interpretation models more easily than if it is completely unknown. In a specific case, substrate nature and enhancement techniques will be known factors. Donor characteristics (e.g. age or diet) can also be known by interviewing the suspect if he/she was identified based on a fingermark comparison (for example through an Automated Fingerprint Identification System (AFIS) database search). On the contrary, the deposition and environmental conditions generally cannot be precisely reconstructed. This is why their impact has to be rigorously investigated in order to choose relevant target compounds.

\subsubsection{Analytical techniques}

The success of a given analytical technique depends upon the nature of the selected target compounds. However, some criteria should be met by these techniques [120], regardless of what compounds are targeted:

- The technique should be easily available in forensic units at affordable prices (availability and costs),

- The technique should be able to differentiate endogenous compounds of fingermarks from possible contaminants (specificity),

- The technique should be able to analyse compounds available in fingermarks left on different kinds of substrates (polyvalence),

- The technique should ideally be non-destructive to the fingermarks in order to allow other analyses to be conducted afterwards (non-destructivity) and should be applicable after enhancement (applicability in routine sequences),

- The technique should allow quick, easy, and reproducible sample preparation and analysis steps (reliability and robustness).

For the analysis of lipids, numerous techniques could be used, but none of them fulfil all the above-mentioned criteria. Among them, GC/MS and FTIR show good potential, as they are both normally available in most forensic laboratories and they are also complementary. While GC/MS allows for the precise identification and differentiation of endogenous compounds and contaminants, FTIR detects only atomic bonds and as such is less specific. On the other hand, fingermarks left on different kinds of substrates (porous and non-porous) can be analysed by GC/MS, while FTIR is optimal for reflective, non-porous surfaces. However, FTIR is non-destructive for fingermarks, while GC/MS requires the extraction of the fingermarks from the substrate using solvents. Finally, FTIR needs minimal sample preparation and can be conducted in situ while GC/MS requires longer extraction and analysis steps. It is also important to note that the extraction efficiency can change dramatically depending upon which solvent is used and that it could be necessary to derivatize some target compounds, which can lead to material losses. 
Furthermore, fluorescent fingermark compounds may also be targeted and these could be analysed by TLC and fluorescence spectroscopy. Again, these techniques do not fulfil all of the criteria. However, while TLC is readily available and allows analysis on nearly every kind of substrate, it also requires fingermark extraction. Similarities may be drawn between fluorescence spectroscopy and FTIR, as they are both commonly available, non-destructive, and provide rapid analysis of samples. However, fluorescence spectroscopy detects the fluorescence of the sample as a whole and cannot really differentiate between endogenous compounds and contaminants. These observations highlight that different analytical techniques can be used to study different target compounds. However, as no technique can fulfil all of the above-mentioned criteria, an iterative process should be carried out to select the most reliable options (Figure 3).

\subsubsection{Aging parameters and models}

To study the aging of fingermarks, aging parameters and models have to be identified, based on target compounds. Aging parameters should show reproducible changes over time and minimize the variability of compounds identified in the fingermark residue caused by influence factors. In order to find such parameters, methodologies applied in other forensic analytical areas were studied. It appeared that in numerous areas, as for example ink dating [121] or drug profiling [122], the use of compound ratios gave good results as it allows achieving mass independency and reduce intrinsic variability. Thus, such ratios were tested between lipid compounds in fingermark residue and also showed good potential [71, 107]. In fact, when numerous fingermarks of one donor were deposited at the same time and analysed with GC/MS over time, ratios of lipids allowed for the construction of reproducible aging curves based on regression parameters following an exponential law. Reproducible regression curves were also used to illustrate the changes in fingermark fluorescence over time, using a ratio of the fluorescence of tryptophan-containing proteins to the oxidation products [96]. Thus, ratios of compounds appear to be an interesting choice to find aging parameters for fingermark dating purposes, as they can correct for sample variability.

Chemometrics, defined as the use of mathematical and statistical tools to obtain information based on chemical data [123, 124], can also be used to model aging using different parameters. For example, Fritz et al. [111] studied changes occurring in fingermarks over time using the FTIR spectral zone of $3000-2800 \mathrm{~cm}^{-1}$ as the aging parameter and plotting their results using principal component analysis (PCA). PCA is a non-supervised, exploratory chemometric tool that allows for the reduction of data complexity by calculating a new coordinate system that contains only the most informative dimensions (called principal components) [123, 124]. This chemometric tool was also used by Girod et al. [112] to highlight the grouping of fingermarks up to 34 days in age. The spectral zones used as aging parameters in this second study were different $\left(3020-2760 \mathrm{~cm}^{-1}, 1800-1500 \mathrm{~cm}^{-1}\right.$, and 1290 $650 \mathrm{~cm}^{-1}$ ) as was the sampling methodology. Chemometric tools were also very recently applied on GC/MS data and allowed the observation of aging patterns among fingermarks exposed to different influence factors [107].

These aging models are still preliminary and much more research needs to be carried out to identify reliable aging parameters and models. The robustness of these parameters when exposed to different influence factors should also be carefully studied and evaluated. While the iterative process to select proper models can be very long, the use of experimental design to reduce the number of experiments that have to be carried out represents a promising approach to tackle this issue [125].

\section{$\underline{\text { 4.1.4. Interpretation models and validation }}$}


When reproducible aging parameters and models have been found, interpretation models must be developed and tested in order to yield reliable elements that will help the inference on the age of a question mark. Dating research has already been conducted for different types of forensic marks (e.g. ink, gunshot residue and blood) and different interpretation models were proposed in the literature based on decision thresholds [126-129], trend tests [130, 131], regression calculations $[60,115,132]$ or likelihood ratios [130, 133, 134]. Concerning fingermarks, aging models based on regression calculations [71, 107], likelihood ratios [107, $120]$ and PCA [107, 111, 112] were reported in the literature. Depending on the approached used, the inference yielded a time interval during which the trace could have been deposited (decision threshold, trend tests), an absolute age within a confidence interval (regression calculations) or a (probabilistic) comparison of two alternatives hypotheses (likelihood ratios and PCA).

All these approaches have merits and drawbacks and can be combined to some extent. Whatever the chosen models, the inferences should always be based on extended research with large datasets of fingermarks and taking influence factors into account. Hence, research efforts should also be focused on the validation of the overall procedures that goes well beyond the usual validation of analytical techniques. The applicability of dating procedures has to be studied on realistic fingermarks deposited and stored in uncontrolled conditions (as close as possible to the reality of forensic casework). This validation generally ends by submitting the procedures and experts to proficiency tests (also called blind tests) [135].

\subsection{Practical considerations}

Once a technique is developed based on the key parameters described above, there are important practical considerations that have to be taken into account prior to its implementation in casework (Figure 3).

\section{$\underline{4.2 .1 . ~ C a s e w o r k ~ c o n t e x t ~}$}

As mentioned above, if a reliable fingermark dating technique is developed, it will not be a quick and easy process and will imply costs that have to be taken into consideration before ordering the necessary analyses. In fact, fingermark dating will likely be reserved for specific cases where the fingermark age is really of crucial importance. The casework context should thus be carefully considered in order to account for the relevancy of conducting fingermark dating. For example, if there are no legitimate explanations for the presence of the question mark at the crime scene, its dating will probably not be necessary [136]. Furthermore, fingermark dating should only be applied on recent cases, recent being defined as corresponding to the lifetime of the targeted compounds (e.g., for lipids, this would be some months). This period of time has to be determined by research and is dependent upon the chosen target compounds. To give an example, if lipids are considered as target compounds, ages between 1 to 3 months could be considered, but probably not older. The influence factors that could potentially have affected the composition of the question mark should also be considered in order to decide if analyses are possible (e.g., was the fingermark stored inside or outside). Research has to yield the necessary information concerning which factors are the most problematic ones. For example, the environmental conditions and the impact of enhancement techniques on fingermark residue should be taken into account, as they can significantly affect target compounds [100, 102, 107].

\subsubsection{Questioned mark and comparison material}

If the dating issue is proven to be relevant and it is possible to analyse it in this particular case, then the collected questioned mark has to be analysed with the appropriate analytical 
techniques based on previous research results (see Figure 3 - left side). The aging parameters of the question mark have to be determined and their values have to be introduced into the aging and interpretation models in order to infer about the age of the questioned mark. These models have to be constructed using relevant comparison material. As mentioned in the literature review, the variability of fingermark chemical characteristics is quite large, particularly between donors. At this stage, it is thus unreasonable to develop a fingermark dating approach applicable to everyone in every possible case scenario. Thus, comparison material should be collected from the suspect's fingermarks in order to build the necessary aging and interpretation models, thus avoiding the inter-variability induced when considering different donors. The suspect must first be identified and localised, either through direct comparison or by comparison with a database (e.g., AFIS). His/her fingermarks should be collected on a substrate similar to the one on which the question mark was found, in order to avoid the substrate effect highlighted in the literature [71, 100, 107]. Different deposition conditions should be investigated based on contextual information and on the activity having led to the question mark. Following these requirements, two different sets of comparison fingermarks should be collected:

- Initial set: numerous fingermarks should be collected on different days at different times and analysed right after collection in order to evaluate the intra-variability of the aging parameters in the suspect's fingermarks at the initial time $(\mathrm{t}=0)$. This intravariability should be sufficiently low to construct reliable aging and interpretation models. If the initial intra-variability is too high, the models would be too variable and dating attempts should be avoided.

- Aging set: numerous fingermarks should be collected and analysed over time at different intervals in order to account for the reproducibility of the aging parameters over time. These comparison fingermarks should be allowed to age as long as it is relevant to the case. This set should be used to develop a specific aging and interpretation model for the particular case being investigated.

Finally, since influence factors affect target compounds and aging parameters in their initial state and over time, comparison fingermarks for the initial and aging sets should be collected under different conditions, based on contextual information. For example, different pressures could be applied during deposition and fingermarks could be aged in different environments. Aging and interpretation models should then take these factors into account. Future research should give precise information about the relevance of such models. However, it can be foreseen that for question marks collected in some unique environments, the constructed models will be unreliable as the fingermarks' induced variability will be too large. This represents the most important limitation of this proposed dating protocol. Yet, this protocol accounts for casework conditions, is up to date, and is the most realistic and scientific approach for fingermark dating proposed to date.

\section{Conclusion}

The case review presented in this article clearly highlights the lack of consensus prevailing worldwide in the way questions about the age of fingermarks are managed. In fact, while the literature generally states that fingermark dating is impossible, numerous expert testimonies contain fingermark age estimations, mostly based on subjective and non-valid parameters, such as the mark "quality" (before or after enhancement). Furthermore, these testimonies are taken into account by the judge and jury and may lead to erroneous or biased conclusions. 
As such dating issues are not new, research has already been conducted on these questions. Different methodologies have been proposed, principally based on the aging of physical (e.g., minutia, ridges) or chemical characteristics (composition) of fingermarks. The aim of these methodologies was principally the same: to identify reproducible measurable aging parameters that can be used to make age estimations. However, none of the fingermark dating techniques proposed to date have been accepted and validated, principally because they are still in early stage of development or because practical considerations were missing from the developments preventing actual use in real forensic caseworks.

Thus, much more research has to be conducted in order to clearly assess the potential of developed methodologies and to prevent the use of erroneous or subjective protocols. Efficient research efforts have to be focused and this article has proposed a formal framework based on the study of chemical characteristics that can be used as a guide to carry out and achieve the necessary research steps. However, due to the labile and variable nature of fingermarks, researchers and practitioners have to keep in mind that fingermark dating will not be applicable to routine casework in a near future. Thus, it is important to comprehensively highlight the potential, as well as the limitations of fingermark dating methodologies to the forensic community.

Finally, it is also important to make a last comment on the practicality of implementing such a fingermark dating method in actual casework. First, it should be clear whether or not there are any legal issues about obtaining multiple impressions of the suspect's prints. In fact, for the usual analyses of fingermarks, such a large amount of comparison prints as described in this article is never necessary and could potentially raise concerns. Problems could also be encountered with uncooperative suspects. A strict protocol should be established in order to assure the quality of the deposited fingermarks, but it has to be kept in mind that similar issues could still be encountered as when Bertillon measurements were taken in the last century (suspect's refusal to leave his/her print resulting in a forced deposition with the help of police officers). Furthermore, a controlled procedure should also be developed in order to avoid the suspect applying external contaminations on purpose on his/her print in an attempt to modify their composition. The privacy aspects should also be considered, as the proposed analyses could reveal chemical information about the suspect (e.g., presence of illegal drug metabolites). However, this concern could probably be solved if the adopted methodologies focus on neutral target compounds, which means compounds that do not reveal any private aspects of the suspect (e.g. lipids).

\section{Acknowledgments}

The authors wish to thank the Swiss National Foundation (SNF no.PP00P1_150742) for its support to Aline Girod and Céline Weyermann, which enabled the preparation of this collaborative article.

\section{References}

[1] Berry J., Stoney D.A. (2001). Chapter 1: The history and development of fingerprinting In: Advances in Fingerprint Technology. Boca Raton: H. C. Lee, R. E. Gaensslen, CRC Press. [2] Cole S. (2001). Suspect identities: a history of fingerprinting and criminal identification: Harvard University Press. 
[3] Sengoopta C. ( 2003). Imprint of the Raj - How fingerprinting was born in colonial India. London: Macmillan.

[4] Weyermann C., Ribaux O. (2012). Situating forensic traces in time. Science and Justice, $52(2) ; 68-75$.

[5] Margot P. (2000). A question of time. Science and Justice, 40 (2); 64-71.

[6] Belcher G.L. (1982). Relative dating of fingerprints. Fingerprint Whorld, 7 (27); 72-3.

[7] McRoberts A.L., Kuhn K.E. (1992). A review of the casereport - "Determining the evaporation rate of latent impressions on the exterior surfaces of aluminium beverage cans". Journal of Forensic Identification, 42 (3); 213-8.

[8] Midkiff C.R. (1993). Lifetime of a latent print. How long? Can you tell? Journal of Forensic Identification, 43 (4); 386-92.

[9] Starrs J.E. (1998). The aging of fingerprints. Scientific Sleuthering Review - Forensic science in courts, $22(2) ; 1-3$.

[10] Wertheim K. (2003). Fingerprint age determination: Is there any hope? Journal of Forensic Identification, 53 (1); 42-9.

[11] Midkiff C.R. (1992). Fingerprints - Determination of time of placement. Fingerprint Whorld, 18 (70); 125-8.

[12] Moenssens A.A. (1969). Fingerprints and the Law. Philadelphia: Chilton Book Company; 26-27.

[13] Champod C., Lennard C., Margot P., Stoilovic M. (2004). Fingerprints and other ridge skin impressions. First ed: CRC Press.

[14] Bowman V. (1998). Manual of fingerprint development techniques. Second ed. London: Police Scientific Development Branch - British Home Office.

[15] McNeil v. State, 227 Md. 298; 176 A.2d 338 (1961).

[16] Beasley v. State, 404 P.2d 911; 81 Nev. 431 (1965).

[17] Stevenson v. United States, 380 F.2d 590 (D.C. Cir., 1967).

[18] Townsley v. United States, 236 A.2d 63 (1967).

[19] Patten v. United States, 248 A.2d 182 (1968).

[20] United States v. Collon (United States v. Garside), 426 F.2d 939 (1970).

[21] Solis v. People, 485 P.2d 903 (1971).

[22] Hearn v. State, 483 S.W.2d 461 (1972).

[23] People v. Fitzgerald, 29 Cal. App. 3d 296 (Cal. Ct. App. 1972).

[24] State v. Granberry, 530 S.W.2d 714 (Mo. Ct. App. 1975).

[25] State v. Pryor, 306 So. 2d 675 (1975).

[26] Commonwealth v. Crawford, 468 Pa. 565; 364 A.2d 660 (1976).

[27] State v. Scott, 251 S.E.2d 414; 296 N.C. 519 (1979).

[28] Commonwealth v. Schroth, 435 A.2d 148; 495 Pa. 561 (1981).

[29] State v. Hulbert, 621 S.W.2d 310 (1981).

[30] State v. Nash, 621 S.W.2d 319 (1981).

[31] State v. Philips, Ohio App. LEXIS 13473 (1981).

[32] Edwards v. State, 660 S.W.2d 622 (1983).

[33] State v. Bradley, 309 S.E.2d 510 (1983).

[34] State v. Wynn, 666 S.W.2d 862 (1984).

[35] Matter of J.M.C., Jr., 502 A.2d 472 (1985).

[36] People v. Joe Butch Santana Jiminez, 188 Cal. App.3d 159; 232 Cal. Rptr. 494; Cal. App. LEXIS 2368 (1986).

[37] Armstrong v. State, 742 P.2d 565 (1987).

[38] Goodwin v. State, 608 A.2d 727, 1992 WL 53432 (Del.Supr 1992).

[39] State v. Cline, 909 P.2d 1171 (1996).

[40] State v. Middlebrook, 725 A.2d 351 (1999). 
[41] Pouncy v. State, 2002 WL 31388799 (tex.App.-Hous. (1 Dist.), 2002).

[42] State v. Clinkscale, 2011 WL 6202436 (Ohio App. 10 Dist., 2011).

[43] United States v. Baller, 519 F.2d 463 (4th Cir. 1975).

[44] Ivey v. State, 176 So.2d 611 (1965).

[45] Levine v. Remolif 80 Nev. 168, 390 P.2d 718, 720 (1964).

[46] Schwabenland J.F. (1992). Case report - Determining the evaporation rate of latent impressions on the exterior surfaces of aluminium beverage cans. Journal of Forensic Identification, 42 (2); 84-90.

[47] Heindl R. (1927). System und Praxis der Daktiloskopie. Third ed. Berlin und Leipzig: Walter de Gruyter \& Co., Vereiningung Wissenschaftlichen Verleger.

[48] Girod A., Ramotowski R., Weyermann C. (2012). Composition of fingermark residue: a qualitative and quantitative review. Forensic Science International, 223 (1-3); 10-24.

[49] Almog J., Sasson Y., Anati A. (1979). Chemical reagents for the development of latent fingerprint, II: Controlled addition of water vapor to iodine fumes - A solution to the aging problem. Journal of Forensic Sciences, 24 (2); 431-6.

[50] Greenlees D. (1994). Age determination-Case report. Fingerprint Whorld, 20 (76); 50-2.

[51] Involdstad H. (1976). How long will a fingerprint last? Fingerprint and Identification Magazine, 57 (9); 4-5.

[52] Brennan J. (1999). Physical developer: temperature considerations. Presented at the 2nd Biennial International Fingerprint Research Group Meeting. Ottawa, Canada.

[53] Bowman V. (2003). Fingerprint development and imaging update. Home Office Scientific Development Branch (HOSDB), Newsletter, 26 (November).

[54] Hoye C. (1977). Ridge persistency. Fingerprint Whorld, 3 (10); 42.

[55] Illsley C. (1984). Super glue fuming and multiple lifts. Identification News, 34 (1).

[56] Clements W.W. (1986). Latent fingerprints - One year later. Fingerprint Whorld, 12 (46).

[57] Barnett P.D., Berger R.A. (1977). The effects of temperature and humidity on the permanency of latent fingerprints. Journal of Forensic Science Society, 16 (3); 249-54.

[58] Bluhm R.J., Lougheed W.J. (1960). Results of time, temperature, and humidity on latent fingerprints. A Flint Police Identification Bureau scientific study. Identification News, 10 (1); 4-12.

[59] Balloch S.R. (1977). The life of a latent. Identification News, 27 (7); 10.

[60] Bremmer R.H., Nadort A., van Leeuwen T.G., van Gemert M.J.C., Aalders M.C.G. (2011). Age estimation of blood stains by hemoglobin derivative determination using reflectance spectroscopy. Forensic Science International, 206 (1-3); 166-71.

[61] Raymond J.J., van Oorschot R.A.H., Gunn P.R., Walsh S.J., Roux C. (2009). Trace evidence characteristics of DNA: A preliminary investigation of the persistence of DNA at crime scenes. Forensic Science International: Genetics, 4 (1); 26-33.

[62] Daubert v. Merrill Dow Pharmaceuticals, 509 U.S. 579 (1993).

[63] National Academy of Sciences (NAS). (2009). Strengthening forensic science in the United States: A path forward. Washington D.C.: Committee on Identifying the Needs of the Forensic Sciences Community, National Research Council.

[64] Howorka H. (1989). Question relating to the determination of the age of objects assuming relevance in criminal investigations. Fingerprint Whorld, 15 (57); 23-8.

[65] Bunter S. (2014). How long can an identifiable fingerprint persist on an exterior surface? CSEye - The home of crime scene science articles, April.

[66] Bunter S. (2007). Fingerprints in paint. Fingerprint Whorld, 34 (130); 21-3.

[67] Davison J. (2007). Duration of latent fingerprints. A case study. Presented at the 6th Biennial International Fingerprint Research Group Meeting. Canberra, Australia. 
[68] Cohen Y., Azoury M., Levin Elad M. (2012). Survivability of latent fingerprints Part II: The effect of cleaning agents on survivability of latent fingerprints. Journal of Forensic Identification, 62 (1); 54-61.

[69] Cohen Y., Rozen E., Azoury M., Attias D., Gavrielli B., Levin Elad M. (2012). Survivability of latent fingerprints Part I: Adhesion of latent fingerprints to smooth surfaces. Journal of Forensic Identification, 62 (1); 47-53.

[70] Almog J., Hirshfeld A., Klug J.T. (1982). Reagents for the chemical development of latent fingerprints: Synthesis and properties of some ninhydrin analogues. Journal of Forensic Sciences, 27 (4); 912-7.

[71] Weyermann C., Roux C., Champod C. (2011). Initial results on the composition of fingerprints and its evolution as a function of time by GC/MS analysis. Journal of Forensic Sciences, 56 (1); 102-8.

[72] De Alcaraz-Fossoul J., Mestres Patris C., Balaciart Muntaner A., Barrot Feixat C., Gené Badia M. (2013). Determination of latent fingerprint degradation patterns - A real fieldwork study. International Journal of Legal Medicine, 127 (4); 857-70.

[73] Barros R.M., Faria B.E.F., Kuckelhaus S.A.S. (2013). Morphometry of latent palmprints as a function of time. Science and Justice, 53 (4); 402-8.

[74] Holyst B. (1987). Kriminalistische Abschätzung des Spurenalters bei Fingerpapillarlinien. Archiv für Kriminologie, 179; 94-103.

[75] Baniuk K. (1990). Determination of age of fingerprints. Forensic Science International, 46 (1-2); 133-7.

[76] Marcinowski M. (2000). Evaluation of fingerprint age determination methods. Problemy Kryminalistyki; 62-8.

[77] Baniuk K. (2000). Polemics - Importance of laboratory experiment in fingerprint age determination. Problemy Kryminalistyki; 69-71.

[78] Aitken C.G.G., Taroni F. (2004). Statistics and the Evaluation of Evidence for Forensic Scientists. Second ed. Chichester, England: John Wiley \& Sons.

[79] Langenburg G., Champod C., Wertheim P. (2009). Testing for potential contextual bias effects during the verification stage of the ACE-V methodology when conducting fingerprint comparisons. Journal of Forensic Sciences, 54 (3); 571-82.

[80] Bynoe S. (2010). President message. Academy News, 40 (5); 1-4.

[81] Popa G., Potorac R., Preda N. (2010). Method for fingerprints age determination. Romanian Journal of Legal Medicine, 18 (2); 149-54.

[82] Merkel R., Gruhn S., Dittmann J., Vielhauer C., Bräutigam A. (2012). On non-invasive 2D and 3D Chromatic White Light image sensors for age determination of latent fingerprints. Forensic Science International, 222 (1-3); 52-70.

[83] Watson P., Prance R.J., Beardsmore-Rust S.T., Prance H. (2011). Imaging electrostatic fingerprints with implications for a forensic timeline. Forensic Science International, 209 (13); 41-5.

[84] Bayford F. (1977). The aging of fingerprints. Fingerprint Whorld, 3 (9); 14.

[85] Johnson P.L. (1973). Life of latents. Identification News, 23 (4); 10-3.

[86] Cantu A., Johnson J. (2001). Chapter 7: Silver physical development of latent prints. In: Advances in Fingerprint Technology, Second ed. Boca Raton: H.C. Lee, R.E. Gaensslen, CRC Press.

[87] Ramotowski R.S. (2001). Chapter 3: Composition of latent print residues In: Advances in Fingerprint Technology. Boca Raton: H.C. Lee, R.E. Gaensslen, CRC Press.

[88] Angst E. (1962). Procédé pour la détermination de l'âge d'empreintes dactyloscopiques sur le papier. Revue internationale de criminologie et de police technique, 16; 134-46. 
[89] Dikshitulu Y.S., Prasad L., Pal J.N., Rao C.V. (1986). Aging studies on fingerprint residues using thin-layer and high performance liquid chromatography. Forensic Science International, 31 (4); 261-6.

[90] Olsen R.D. (1987). Chemical dating techniques for latent fingerprints: A preliminary report. The Identification News; 10-2.

[91] Dalrymple B.E., Duff J.M., Menzel E.R. (1977). Inherent fingerprint luminescence Detection by laser. Journal of Forensic Sciences, 22 (1); 106-15.

[92] Duff J.M., Menzel E.R. (1978). Laser assistedted thin-layer chromatography and luminescence of fingerprints: An approach to fingerprint age determination. Journal of Forensic Sciences, 23 (1); 129-34.

[93] Menzel E.R. (1992). Fingerprint age determination by fluorescence. Journal of Forensic Sciences, 37 (5); 1212-3.

[94] Lambrechts S.A.G., van Dam A., de Vos J., van Weert A., Sijen T., Aalders M.C.G. (2012). On the autofluorescence of fingermarks. Forensic Science International, 222 (1-3); 89-93.

[95] van Dam A., Aalders M.C.G., Todorovski T., van Leeuwen T.G., Lambrechts S.A.G. (2016). On the autofluorescence of aged fingermarks. Forensic Science International, 258; 1925.

[96] van Dam A., Schwarz J.C.V., de Vos J., Siebes M., Sijen T., van Leeuwen T.G., et al. (2014). Oxidation monitoring by fluorescence spectroscopy reveals the age of fingermarks. Angewandte Chemie, 53 (24); 6272-5.

[97] De Paoli G., Lewis Sr S.A., Schuette E.L., Lewis L.A., Connatser R.M., Farkas T. (2010). Photo- and thermal-degradation studies of select eccrine fingerprint constituents. Journal of Forensic Sciences, 55 (4); 962-9.

[98] Buchanan M.V., Asano K., Bohanon A. (1996). Chemical characterization of fingerprints from adults and children. Forensic Evidence Analysis and Crime Scene Investigation, SPIE (International Society for Optical Engineering), 2941; 89-95.

[99] Asano K.G., Bayne C.K., Horsman K.M., Buchanan M.V. (2002). Chemical composition of fingerprints for gender determination. Journal of Forensic Sciences, 47 (4); 805-7.

[100] Archer N.E., Charles Y., Elliott J.A., Jickells S. (2005). Changes in the lipid composition of latent fingerprint residue with time after deposition on a surface. Forensic Science International, 154 (2-3); 224-39.

[101] Jickells S.M. (2008). Fingerprinting: Into the future. Measurement and Control, 41 (8); 243-7.

[102] Koenig A., Girod A., Weyermann C. (2011). Identification of wax esters in fingermark residues by GC/MS and their potential use as aging parameters. Journal of Forensic Identification, 61 (6); 652-76.

[103] Girod A., Weyermann C. (2014). Lipid composition of fingermark residue and donor classification using GC/MS. Forensic Science International, 238; 68-82.

[104] Mong G.M., Petersen C.E., Clauss T.R.W. (1999). Advanced fingerprint analysis project: Final report - Fingerprint constituents. Pacific Northwest National Laboratory.

[105] Croxton R.S., Baron M.G., Butler D., Kent T., Sears V.G. (2006). Development of a GC-MS method for the simultaneous analysis of latent fingerprint components. Journal of Forensic Sciences, 51 (6); 1329-33.

[106] Croxton R.S., Baron M.G., Butler D., Kent T., Sears V.G. (2010). Variation in amino acid and lipid composition of latent fingerprints. Forensic Science International, 199 (1-3); 93-102.

[107] Girod A., Spyratou A., Holmes D., Weyermann C. (2016). Aging of target lipid compounds in fingermark residue using GC/MS: effects of influence factors and perspectives for dating purposes. Science and Justice, (accepted in December 2015). 
[108] Humecki H. (1985). Experiments in ballpoint ink aging using infrared spectroscopy. Presented at the International Symposium on Questioned Documents. Forensic Science Research and Training Center, F.B.I. Academy, Quantico, VA.

[109] Antoine K.M., Mortazavi S., Miller A.D., Miller L.M. (2010). Chemical differences are observed in children's versus adults' latent fingerprints as a function of time. Journal of Forensic Sciences, 55 (2); 513-8.

[110] Hemmila A., McGill J., Ritter D. (2008). Fourier transform infrared reflectance spectra of latent fingerprints: a biometric gauge for the age of an individual. Journal of Forensic Sciences, 53 (2); 369-76.

[111] Fritz P., van Bronswjik W., Lepkova K., Lewis S.W., Lim K.F., Martin D.E., et al. (2013). Infrared microscopy studies of the chemical composition of latent fingermark residues. Microchemical Journal, 111 (0); 40-6.

[112] Girod A., Xiao L., Reedy B., Roux C., Weyermann C. (2015). Fingermark initial composition and aging using Fourrier transform infrared microscopy ( $\mu$-FTIR). Forensic Science International, 254 (September); 185-96.

[113] Bright N.J., Willson, T.R., Driscoll, D.J., Reddy, S.M., Webb, R.P., Bleay, S., Ward, N.I., Kirkby, K.J., Bailey, M.J. (2013). Chemical changes exhibited by latent fingerprints after exposure to vacuum conditions. Forensic Science International, 230 (1-3); 81-6.

[114] Edelman G.J., Gaston E., van Leeuwen T.G., Cullen P.J., Aalders M.C.G. (2012). Hyperspectral imaging for non-contact analysis of forensic traces. Forensic Science International, 223 (1-3); 28-39.

[115] Edelman G., van Leeuwen T.G., Aalders M.C.G. (2012). Hyperspectral imaging for the age estimation of blood stains at the crime scene. Forensic Science International, 223 (1-3); 72-7.

[116] Edelman G.J. (2014). Spectral analysis of blood stains at the crime scene. PhD Thesis, University of Amsterdam.

[117] Wolstenholme R., Bradshaw R., Clench M.R., Francese S. (2009). Study of latent fingermarks by matrix-assisted laser desorption/ionisation mass spectrometry imaging of endogenous lipids. Rapid Communications in Mass Spectrometry, 23; 3031-9.

[118] Sisco E., Demoranville L.T., Gillen G. (2013). Evaluation of C60 secondary ion mass spectrometry for the chemical analysis and imaging of fingerprints. Forensic Science International, 231 (1-3); 263-9.

[119] Bailey M.J., Jones B.N., Hinder S., Watts J., Bleay S., Webb R.P. (2010). Depth profiling of fingerprint and ink signals by SIMS and MeV SIMS. Nuclear Instruments and Methods in Physics Research Section B: Beam Interactions with Materials and Atoms, 268 (11-12); 1929-32.

[120] Girod A., Roux C., Weyermann C. (2014). La datation des traces digitales (partie II): proposition d'une approche formelle. Revue internationale de criminologie et de police technique, 68 (2); 226-49.

[121] Koenig A., Weyermann C. (2014). Evaluation of ballpoint pen ink ageing parameters using GC/MS analyses. Presented at the 8th European Document Experts Working Group Conference. Ankara, Turkey.

[122] Esseiva P., Gaste, L., Alvarez, D., Anglada, F. (2011). Illicit drug profiling, reflection on statistical comparisons. Forensic Science International, 207; 27-34.

[123] Massart D.L., Vandeginste, B. G. M., Buydens, L.M.C., De Jong, S., Lewi, P.J., Smeyers-Verbeke, J. (1997). Data handling in science and technology 20A: Handbook of chemometrics and qualimetrics, Part A. Amsterdam: Elsevier.

[124] Miller J.N., Miller J.C. (2005). Statistics and chemometrics for analytical chemistry. Fifth ed: Pearson, Prentice Hall. 
[125] Esbensen K.H., Guyot D., Westad F., Houmøller L.P. (2002). Multivariate data analysis in practice: an introduction to multivariate data analysis and experimental design. Fifth ed. Oslo: Camo Process AS.

[126] Aginsky V. (1996). Dating and characterizing writing, stamp, pad, and jet printer inks by gas chromatography/mass spectrometry. International Journal of Forensic Document Examiners, 2 (2); 103-16.

[127] Bugler J.H., Buchner H., Dallmayer A. (2008). Age determination of ballpoint pen ink by thermal desorption and gas chromatography-mass spectrometry. Journal of Forensic Sciences, 53 (4); 982-8.

[128] Gaudreau M., Aginsky V. (2010). Essentials of the solvent loss ratio method. Presented at the 68th Annual Conference of the American Society of Questionned Document Examiners. Victoria, British Columbia, Canada.

[129] Persin B., Touron P., Mille F., Bernier G., Subercazes T. (2007). Evaluation de la date d'un tir. Canadian Society of Forensic Science Journal, 40 (2); 65-8.

[130] Weyermann C., Almog J., Bügler J., Cantu A.A. (2011). Minimum requirements for application of ink dating methods based on solvent analysis in casework. Forensic Science International, 210 (1-3); 52-62.

[131] Koenig A., Bügler J., Kirsch D., Köhler F., Weyermann C. (2015). Ink dating using thermal desorption and gas chromatography / mass spectrometry: Comparison of results obtained in two laboratories. Journal of Forensic Science, 60 (Issue Supplement S1); 152-61.

[132] Andrasko J., Norberg T., Stahling S. (1998). Time since discharge of shotguns. Journal of Forensic Sciences, 43 (5); 1005-15.

[133] Weyermann C., Schiffer B., Margot P. (2008). A logical framework to ballpoint ink dating interpretation. Science and Justice, 48 (3); 118-25.

[134] Gallidabino M., Weyermann C., Romolo F.S., Taroni F. (2013). Estimating the time since discharge of spent cartridges: A logical approach for interpreting the evidence. Science and Justice, 53 (1); 41-8.

[135] Almog J., Cantu A.A., Champod C., Kent T., Lennard C. (2014). Guidelines for the assessment of fingermark detection techniques. International Fingerprint Research Group (IFRG). Journal of Forensic Identification, 64 (2); 174-97.

[136] Margot P. (2014). Traçologie: la trace, vecteur fondamental de la police scientifique. Revue internationale de criminologie et de police technique, 67 (1); 72-97. 
Figure 1: Natural fingermarks on glass slides imaged in transmission mode with black background and stored in a box during (from left to right): 10 minutes, 1 day, and 5 weeks. No difference in the "quality" of the fingermarks is visible.

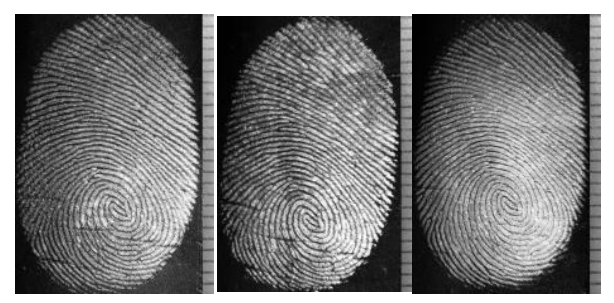


Figure 2: Lifted fingermarks enhanced on glass slides using aluminium fingermark powder (also called "Argentoratum") and stored in a box during (from left to right): 10 minutes, 1 hour, and 6 weeks. The quality of the enhancement decreased slightly, while the background noise increased very quickly. However, no significant difference can be observed in the "quality" of fingermarks after 1 hour compared to 6 weeks.

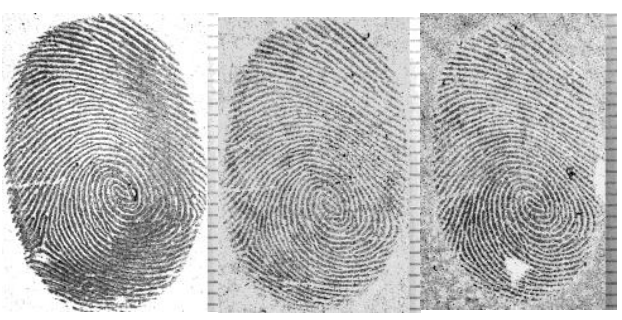


Figure 3: Proposed approach to address the fingermark dating issue considering the research (left) that has to be carried out prior to any potential practical application (right).

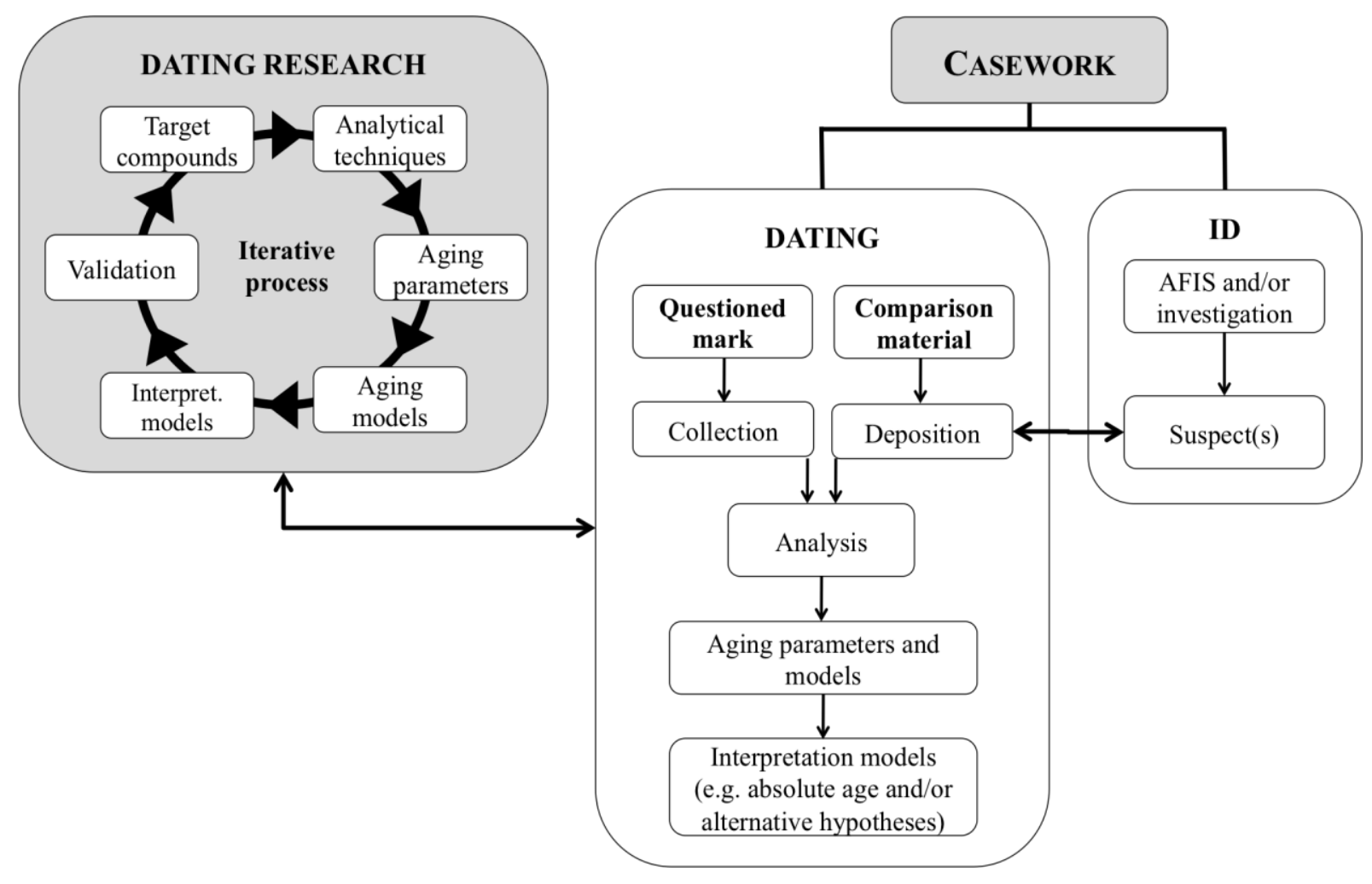


Table 1: A summary of 28 court cases from the United States of America in which the age of fingermarks was discussed. The complete legal citations for these cases are given in the references.

\begin{tabular}{|c|c|c|c|c|c|c|c|}
\hline \# & $\begin{array}{l}\text { Court cases } \\
\text { (USA) }\end{array}$ & Type of crime & $\begin{array}{c}\text { Fingermark } \\
\text { substrate }\end{array}$ & $\begin{array}{l}\text { Fingermark age } \\
\text { testimony }\end{array}$ & $\begin{array}{l}\text { Alternative } \\
\text { explanation } \\
\text { for the } \\
\text { presence of } \\
\text { fingermark? }\end{array}$ & $\begin{array}{l}\text { Appellate } \\
\text { Review } \\
\text { Outcome }\end{array}$ & $\begin{array}{c}\text { Year } \\
\text { of } \\
\text { Appeal }\end{array}$ \\
\hline 1 & $\begin{array}{l}\text { McNeil v. } \\
\text { State [15] }\end{array}$ & $\begin{array}{l}\text { breaking and } \\
\text { entering (with intent } \\
\text { to steal goods worth } \\
\text { at least } \$ 100 \text { ) }\end{array}$ & beer bottles & $\begin{array}{l}\text { Court: The expert } \\
\text { testified that the } \\
\text { fingerprint had been } \\
\text { left on the bottle not } \\
\text { more than } \mathbf{1 8} \text { hours } \\
\text { prior to the crime. }\end{array}$ & no & $\begin{array}{l}\text { judgment } \\
\text { affirmed }\end{array}$ & 1961 \\
\hline 2 & $\begin{array}{l}\text { Beasley v. } \\
\text { State [16] }\end{array}$ & $\begin{array}{l}\text { murder, } \\
\text { first degree }\end{array}$ & car & $\begin{array}{l}\text { Court: The expert "was } \\
\text { allowed to express an } \\
\text { opinion as to the time } \\
\text { appellant's finger and } \\
\text { palm prints were } \\
\text { placed"; "To allow him } \\
\text { to so testify was } \\
\text { prejudicial error." }\end{array}$ & no & $\begin{array}{l}\text { judgment } \\
\text { reversed }\end{array}$ & 1965 \\
\hline 3 & $\begin{array}{c}\text { Stevenson } v . \\
\text { United States } \\
\text { and Borum } v . \\
\text { United States } \\
\quad[17]\end{array}$ & $\begin{array}{l}\text { housebreaking; } \\
\text { robbery }\end{array}$ & $\begin{array}{l}\text { metal box; } \\
\text { bedside } \\
\text { table glass; } \\
\text { tin tea } \\
\text { canister }\end{array}$ & $\begin{array}{l}\text { Court: Expert testified } \\
\text { that under ideal } \\
\text { conditions these } \\
\text { fingerprints could last } \\
\text { up to two years. }\end{array}$ & no & $\begin{array}{l}\text { judgments } \\
\text { affirmed }\end{array}$ & 1967 \\
\hline 4 & $\begin{array}{c}\text { Townsley v. } \\
\text { United States } \\
{[18]}\end{array}$ & $\begin{array}{l}\text { attempted house } \\
\text { breaking; } \\
\text { destroying property; } \\
\text { petit larceny }\end{array}$ & $\begin{array}{c}\text { glass } \\
\text { fragments }\end{array}$ & $\begin{array}{l}\text { Court: Expert testified } \\
\text { that impressions could } \\
\text { have been left on the } \\
\text { glass a day before the } \\
\text { crimes were committed. }\end{array}$ & yes & $\begin{array}{l}\text { judgment } \\
\text { reversed }\end{array}$ & 1967 \\
\hline 5 & $\begin{array}{l}\text { Patten v. } \\
\text { State [19] }\end{array}$ & $\begin{array}{l}\text { attempted } \\
\text { housebreaking; } \\
\text { destruction of } \\
\text { private property; } \\
\text { possession of } \\
\text { implements of } \\
\text { crime }\end{array}$ & paper bag & $\begin{array}{l}\text { Court: Expert admitted } \\
\text { that the prints could } \\
\text { have been on the bag } \\
\text { for as long as six } \\
\text { months and that mere } \\
\text { incidental touching } \\
\text { would not have } \\
\text { produced such prints. }\end{array}$ & no & $\begin{array}{l}\text { judgment } \\
\text { affirmed }\end{array}$ & 1968 \\
\hline 6 & $\begin{array}{l}\text { United States } \\
\text { v. Collon and } \\
\text { United States } \\
\text { v. Garside [20] }\end{array}$ & robbery & map & $\begin{array}{l}\text { Court: Expert testified } \\
\text { that the fingerprints } \\
\text { could have been on the } \\
\text { map for an indefinite } \\
\text { period of time, at least } \\
\text { for many months. }\end{array}$ & yes & $\begin{array}{l}\text { judgment } \\
\text { reversed } \\
\text { (Garside); } \\
\text { judgment } \\
\text { affirmed } \\
\text { (Collon) } \\
\end{array}$ & 1970 \\
\hline 7 & $\begin{array}{c}\text { Solis v. } \\
\text { People [21] }\end{array}$ & burglary & $\begin{array}{l}\text { fragments of } \\
\text { broken glass }\end{array}$ & $\begin{array}{l}\text { Court: Expert stated } \\
\text { that latent prints would } \\
\text { remain for about two } \\
\text { years, unless they were } \\
\text { exposed to the } \\
\text { elements. }\end{array}$ & yes & $\begin{array}{l}\text { judgment } \\
\text { reversed }\end{array}$ & 1971 \\
\hline 8 & $\begin{array}{l}\text { Hearn } v . \\
\text { State [22] }\end{array}$ & burglary & safe & $\begin{array}{l}\text { Court: Expert } \\
\text { indicated that the print } \\
\text { was put on the safe } \mathbf{1 0} \\
\text { to } \mathbf{2 4} \text { hours prior to } \\
\text { the time it was lifted. }\end{array}$ & no & $\begin{array}{l}\text { judgment } \\
\text { affirmed }\end{array}$ & 1972 \\
\hline 9 & $\begin{array}{c}\text { People v. } \\
\text { Fitzgerald [23] }\end{array}$ & $\begin{array}{l}\text { murder, } \\
\text { first degree }\end{array}$ & $\begin{array}{l}\text { chrome strip } \\
\text { on car door }\end{array}$ & $\begin{array}{l}\text { Court: Expert testified } \\
\text { that the latent } \\
\text { thumbprint was fresh, } \\
\text { meaning one day old, } \\
\text { because a fresh print } \\
\text { usually grabs the } \\
\text { powder readily. }\end{array}$ & no & $\begin{array}{l}\text { judgment } \\
\text { affirmed }\end{array}$ & 1972 \\
\hline
\end{tabular}




\begin{tabular}{|c|c|c|c|c|c|c|c|}
\hline 10 & $\begin{array}{c}\text { State v. } \\
\text { Granberry [24] }\end{array}$ & $\begin{array}{l}\text { murder, } \\
\text { first degree }\end{array}$ & car & $\begin{array}{l}\text { Court: Expert stated it } \\
\text { is difficult to determine } \\
\text { the age of the } \\
\text { fingerprint; could } \\
\text { provide an "educated } \\
\text { guess" that it was } \\
\text { "fresh" from } 2 \text { to } 24 \\
\text { hours old. }\end{array}$ & no & $\begin{array}{l}\text { judgment } \\
\text { affirmed }\end{array}$ & 1975 \\
\hline 11 & $\begin{array}{l}\text { State v. } \\
\text { Pryor }[25]\end{array}$ & $\begin{array}{l}\text { burglary } \\
\text { (simple) }\end{array}$ & $\begin{array}{l}\text { filing } \\
\text { cabinet }\end{array}$ & $\begin{array}{l}\text { Court: Paraphrased } \\
\text { Moenssens [12]: } \\
\text { “...fingerprints may be } \\
\text { developed by } \\
\text { powdering (as was } \\
\text { done here) only during } \\
\text { the first week or so..." }\end{array}$ & no & $\begin{array}{l}\text { judgment } \\
\text { affirmed }\end{array}$ & 1975 \\
\hline 12 & $\begin{array}{c}\text { Commonwealth } \\
\text { v. Crawford } \\
{[26]}\end{array}$ & $\begin{array}{l}\text { murder, } \\
\text { first degree }\end{array}$ & car & $\begin{array}{l}\text { Court: Expert testified } \\
\text { that the prints identified } \\
\text { as belonging to } \\
\text { appellant were placed } \\
\text { on the car at the time } \\
\text { of the commission of } \\
\text { the crime. }\end{array}$ & no & $\begin{array}{l}\text { judgment } \\
\text { reversed }\end{array}$ & 1976 \\
\hline 13 & $\begin{array}{c}\text { State v. } \\
\text { Scott [27] }\end{array}$ & homicide & metal box & $\begin{array}{l}\text { Court: Expert testified } \\
\text { that the thumbprint } \\
\text { might have been placed } \\
\text { in the box several } \\
\text { weeks before the } \\
\text { homicide. }\end{array}$ & yes & $\begin{array}{l}\text { judgment } \\
\text { reversed }\end{array}$ & 1979 \\
\hline 14 & $\begin{array}{l}\text { Commonwealth } \\
\text { v. Schroth [28] }\end{array}$ & $\begin{array}{l}\text { murder, } \\
\text { first degree }\end{array}$ & $\begin{array}{l}\text { apartment } \\
\text { door }\end{array}$ & $\begin{array}{l}\text { Expert: "There is no } \\
\text { accurate way to } \\
\text { determine the age of a } \\
\text { print"; "This is a } \\
\text { comparatively fresh } \\
\text { print"; "....it could be } \\
\text { six hours, twelve } \\
\text { hours old." }\end{array}$ & no & $\begin{array}{l}\text { judgment } \\
\text { reversed }\end{array}$ & 1981 \\
\hline 15 & $\begin{array}{c}\text { State v. } \\
\text { Hulbert [29] }\end{array}$ & $\begin{array}{l}\text { burglary, } \\
\text { second degree }\end{array}$ & $\begin{array}{l}\text { fragments of } \\
\text { broken } \\
\text { window } \\
\text { (glass) }\end{array}$ & $\begin{array}{l}\text { Court: Expert testified } \\
\text { that the prints were } \\
\text { relatively fresh, that is, } \\
\text { deposited there within } \\
\text { the previous two days } \\
\text { and that the powder } \\
\text { went on "fast" }\end{array}$ & no & $\begin{array}{l}\text { judgment } \\
\text { affirmed }\end{array}$ & 1981 \\
\hline 16 & $\begin{array}{l}\text { State v. } \\
\text { Nash [30] }\end{array}$ & $\begin{array}{c}\text { burglary, } \\
\text { first degree and } \\
\text { rape }\end{array}$ & $\begin{array}{l}\text { sliding glass } \\
\text { door }\end{array}$ & $\begin{array}{l}\text { Court: Expert testified } \\
\text { that the print was dark, } \\
\text { clear and fresh and } \\
\text { that in adverse weather } \\
\text { conditions the prints } \\
\text { would deteriorate } \\
\text { rapidly and in a matter } \\
\text { of days. }\end{array}$ & no & $\begin{array}{l}\text { judgment } \\
\text { affirmed }\end{array}$ & 1981 \\
\hline 17 & $\begin{array}{c}\text { State v. } \\
\text { Philips [31] }\end{array}$ & $\begin{array}{c}\text { aggravated } \\
\text { robbery/aggravated } \\
\text { burglary }\end{array}$ & $\begin{array}{c}\text { stolen } \\
\text { merchandise }\end{array}$ & $\begin{array}{l}\text { Court: Expert stated } \\
\text { that no method exist to } \\
\text { scientifically determine } \\
\text { age of fingerprints; } \\
\text { characterized prints as } \\
\text { "quality" and "fresh" } \\
\text { and with "good } \\
\text { contrast" }\end{array}$ & no & $\begin{array}{l}\text { judgment } \\
\text { affirmed }\end{array}$ & 1981 \\
\hline 18 & $\begin{array}{l}\text { Edwards } v . \\
\text { State [32] }\end{array}$ & $\begin{array}{l}\text { murder, } \\
\text { capital }\end{array}$ & $\begin{array}{l}\text { unspecified } \\
\text { (crime } \\
\text { scene) }\end{array}$ & $\begin{array}{l}\text { Court: Expert stated } \\
\text { that the prints were } \\
\text { fresh or recent as } \\
\text { opposed to being six } \\
\text { months old. }\end{array}$ & no & $\begin{array}{l}\text { judgment } \\
\text { affirmed }\end{array}$ & 1983 \\
\hline 19 & $\begin{array}{c}\text { State v. } \\
\text { Bradley [33] }\end{array}$ & $\begin{array}{l}\text { felonious breaking } \\
\text { and entering }\end{array}$ & $\begin{array}{l}\text { broken } \\
\text { pieces of } \\
\text { window }\end{array}$ & $\begin{array}{l}\text { Court: Expert testified } \\
\text { that the palm print } \\
\text { could have remained on }\end{array}$ & no & $\begin{array}{l}\text { judgment } \\
\text { reversed }\end{array}$ & 1983 \\
\hline
\end{tabular}




\begin{tabular}{|c|c|c|c|c|c|c|c|}
\hline & & & glass & $\begin{array}{l}\text { the window for six } \\
\text { months. }\end{array}$ & & & \\
\hline 20 & $\begin{array}{c}\text { State v. } \\
\text { Wynn [34] }\end{array}$ & $\begin{array}{c}\text { burglary, } \\
\text { second degree; } \\
\text { stealing in excess of } \\
\$ 150.00\end{array}$ & $\begin{array}{l}\text { glass beer } \\
\text { mug }\end{array}$ & $\begin{array}{l}\text { Expert: Print "... was } \\
\text { one of the last things } \\
\text { on the glass itself" and } \\
\text { that it was "relatively } \\
\text { fresh, as opposed to } \\
\text { being several weeks } \\
\text { old. By relatively fresh } \\
\text { I mean several days." }\end{array}$ & no & $\begin{array}{l}\text { judgment } \\
\text { affirmed }\end{array}$ & 1984 \\
\hline 21 & $\begin{array}{l}\text { In re J.M.C., } \\
\quad J r . \text { [35] }\end{array}$ & burglary/theft & $\begin{array}{l}\text { air freshener } \\
\text { can in } \\
\text { bathroom }\end{array}$ & $\begin{array}{l}\text { Court: Expert testified } \\
\text { that the print could } \\
\text { have been there over a } \\
\text { year (as opposed to } \\
\text { being placed there at } \\
\text { the time of the crime). }\end{array}$ & yes & $\begin{array}{l}\text { judgment } \\
\text { reversed }\end{array}$ & 1985 \\
\hline 22 & $\begin{array}{c}\text { People v. } \\
\text { Jiminez [36] }\end{array}$ & $\begin{array}{l}\text { murder, } \\
\text { second degree; } \\
\text { manslaughter } \\
\text { (voluntary) }\end{array}$ & beer cans & $\begin{array}{l}\text { Court: Expert } \\
\text { concluded that both the } \\
\text { fingerprint and tire } \\
\text { tracks were not more } \\
\text { than } 24 \text { hours old. }\end{array}$ & no & $\begin{array}{l}\text { judgment } \\
\text { affirmed }\end{array}$ & 1986 \\
\hline 23 & $\begin{array}{l}\text { Armstrong } v . \\
\text { State [37] }\end{array}$ & $\begin{array}{l}\text { burglary, } \\
\text { second degree }\end{array}$ & $\begin{array}{l}\text { inside cash } \\
\text { drawer }\end{array}$ & $\begin{array}{l}\text { Court: Expert testified } \\
\text { that the fingerprint was } \\
\text { fresh because of the } \\
\text { amount of powder it } \\
\text { picked up, indicating } \\
\text { the print was still moist } \\
\text { and newly made. }\end{array}$ & no & $\begin{array}{l}\text { judgment } \\
\text { affirmed }\end{array}$ & 1987 \\
\hline 24 & $\begin{array}{l}\text { Goodwin v. } \\
\text { State [38] }\end{array}$ & $\begin{array}{c}\text { kidnapping, } \\
\text { first and second } \\
\text { degree; unlawful } \\
\text { sexual intercourse }\end{array}$ & $\begin{array}{c}\text { car } \\
\text { interior }\end{array}$ & $\begin{array}{l}\text { Court: Expert } \\
\text { concluded that the } \\
\text { prints found in the } \\
\text { victim's car were } \\
\text { recent [i.e., within } \mathbf{2 4} \\
\text { hours] based on his } \\
\text { experience. }\end{array}$ & no & $\begin{array}{l}\text { judgment } \\
\text { affirmed }\end{array}$ & 1992 \\
\hline 25 & $\begin{array}{l}\text { State v. } \\
\text { Cline [39] }\end{array}$ & $\begin{array}{c}\text { robbery, burglary, } \\
\text { and aggravated } \\
\text { assault }\end{array}$ & $\begin{array}{l}\text { envelope } \\
\text { flap }\end{array}$ & $\begin{array}{l}\text { Expert: this was a } \\
\text { "fresh latent print } \\
\text { probably about a } \\
\text { month or two old"; } \\
\text { “...there is leeway } \\
\text { either way." }\end{array}$ & no & $\begin{array}{l}\text { judgment } \\
\text { reversed }\end{array}$ & 1996 \\
\hline 26 & $\begin{array}{c}\text { State vs. } \\
\text { Middlebrook } \\
\text { [40] }\end{array}$ & $\begin{array}{l}\text { burglary, } \\
\text { third degree; } \\
\text { larceny, } \\
\text { first degree; } \\
\text { criminal mischief, } \\
\text { third degree }\end{array}$ & $\begin{array}{l}\text { aluminium } \\
\text { storm door } \\
\text { frame }\end{array}$ & $\begin{array}{l}\text { Court: Expert testified } \\
\text { that weather conditions } \\
\text { could affect the quality } \\
\text { and longevity of a } \\
\text { latent print and that a } \\
\text { fingerprint found inside } \\
\text { of a storm door would } \\
\text { last longer than one } \\
\text { found on the outside. }\end{array}$ & no & $\begin{array}{l}\text { judgment } \\
\text { affirmed }\end{array}$ & 1999 \\
\hline 27 & $\begin{array}{l}\text { Pouncy } v . \\
\text { State [41] }\end{array}$ & $\begin{array}{l}\text { robbery, } \\
\text { aggravated }\end{array}$ & cigar box & $\begin{array}{l}\text { Court: Expert testified } \\
\text { that the fingerprint } \\
\text { discovered at scene of } \\
\text { burglary was less than } \\
\mathbf{4 8} \text { hours old and } \\
\text { confirmed that the } \\
\text { fingerprint he lifted } \\
\text { from the cigar box was } \\
\text { fresh. }\end{array}$ & no & $\begin{array}{l}\text { judgment } \\
\text { affirmed }\end{array}$ & 2002 \\
\hline 28 & $\begin{array}{c}\text { State } v . \\
\text { Clinkscale [42] }\end{array}$ & $\begin{array}{c}\text { murder, } \\
\text { aggravated (prior } \\
\text { calculation); } \\
\text { murder, } \\
\text { attempted } \\
\text { aggravated; } \\
\text { robbery, } \\
\text { aggravated; }\end{array}$ & $\begin{array}{l}\text { video game } \\
\text { controller; } \\
\text { booklet }\end{array}$ & $\begin{array}{l}\text { Expert: “...this print } \\
\text { did not exhibit any } \\
\text { deterioration at all. It } \\
\text { had clear ridge detail. } \\
\text { So, in my opinion that } \\
\text { was newly deposited." }\end{array}$ & no & $\begin{array}{l}\text { judgment } \\
\text { affirmed }\end{array}$ & 2011 \\
\hline
\end{tabular}


Draft for Forensic Science International (as a Review Article)

burglary, aggravated 